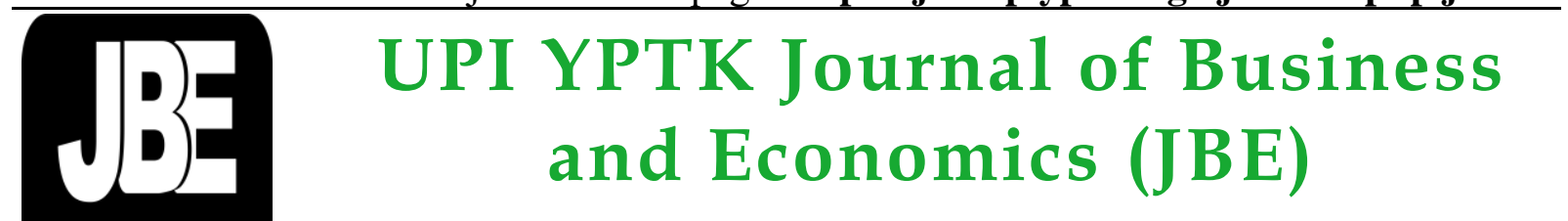

UPI YPTK JBE

\title{
The Effect of Audit Rotation, Audit Tenure and Auditor Reputation on Audit Quality: Profitability as Moderating Variable
}

\author{
Mia Austina Anggraini ${ }^{1}$, Sigit Sanjaya ${ }^{2 *}$, Yamasitha $^{3}$, Yulasmi $^{4}$ \\ 1,2,3 Department of Accounting, Faculty of Economics and Business, Universitas Putra Indonesia YPTK \\ ${ }^{4}$ Departement of Management, Faculty of Economics and Business, Universitas Putra Indonesia YPTK \\ *sigitsanjaya@upiyptk.ac.id
}

\begin{abstract}
This study aims to determine the effect of Audit Tenure, Audit Committee and Auditor Reputation on Audit Quality with Profitability as a Moderation variable. The sample used is a manufacturing company listed on the Indonesia Stock Exchange (BEI) 2015-2019. In determining the sample using the purposive sampling method. The data used are secondary data and the method of analysis used is logistic regression analysis. The results showed that partially Audit Rotation has a positive and significant effect on Audit Quality with a significant value of 0,012 . Audit Tenure has a positive and no significant effect on Audit Quality with a significant value of 0,346. Auditor Reputation has a positive and significant effect on Audit Quality with a significant value of 0,028. Audit Rotation has a positive and significant effect on Audit Quality with Profitability as a moderating variable with no significant value of 0,655. Audit Tenure has a positive and significant effect on Audit Quality with Profitability as a moderating variable with no significant value of 0,720 . Partially, Auditor Reputation has a positive and significant effect on Audit Quality with Profitability as a moderating variable with a significant value of 0,000. Simultaneously the Audit Tenure, Audit Committee and Auditor Reputation have a positive and significant effect on Audit Quality with profitability as a moderating variable with a significant value of 0,003 .
\end{abstract}

Keywords: Audit Quality, Audit Rotation, Audit Tenure, Auditor Reputation, Profitability

\section{Introduction}

The company is responsible for carrying out all economic activities or transactions from technological developments and national economic growth as outlined in financial statements. Information that will be used as consideration in making a decision. Auditing is a service provided by the auditor in examining and evaluating the financial statements presented by the company. Examination of financial statements is intended to assess the fairness of financial statements. A company requires professional services in auditing its company so that the financial statements prepared by the management can provide confidence for users of accounting information, that the financial statements have been presented by accounting standards and can be used as a reference in making decisions. Public accountants carry out these professional services. Public accountants are competent and independent parties in auditing financial statements. Competition in public accounting services makes public accountants pay attention to survive in the fierce competition in the business world to gain the public's trust.

Financial reports are the only source of information for shareholders. By conducting an audit, the information available in the financial statements becomes relevant and reliable for shareholders and other interested parties (Zahra IsmiFauziyyah, 2020). The audit quality results are used to increase the credibility of the financial statements of users of accounting information to reduce the risk of information that is not the credibility of information in financial statements for users of financial statements, especially investors. Audit quality is essential in maintaining trust in the integrity of financial reporting. The Public Company Accounting Oversight Board

Accepted by editor: December 24, 2021 | Final Revision: December 26, 2021 | Online Publication: Jan 02, 2022 
(PCAOB) (2015: 3) defines audit quality as meeting investors' needs for an independent and reliable audit and strong audit committee communication. (NinikAndriani, 2017) Going Concern opinion in this study is used as a proxy for audit quality variables. Going Concern can be defined as the survival of an entity. In going concern accounting, it is defined as the company's ability to be able to maintain its business activities and continue to function as a business entity.

The concept of audit quality states that to achieve a quality audit, the auditor must have competence and independence. Independence has a critical role in determining the audit's quality because independence is related to acting objectively (impartially) and full of integrity. An independent attitude will cause the client's financial statements to be free from bias elements. However, to have an independent attitude, the auditor will be influenced by various factors: the length of the audit engagement (tenure) between the auditor and a client company (Rizkiani, 2019). Audit quality is a tendency that the auditor will carry out in detecting and disclosing the existence of fraud in the client's financial statements.

Audit quality is good if the auditor can assure no material misstatement of the finances being audited (Rasmini, 2016). To maintain the trust of users of audited financial statements, Public Accountants must pay attention to the quality of the audits they produce. Although auditors must provide quality audits, these demands have not been fully met because there are still many financial scandals involving auditors. And now, a few people in the community have lost their trust in auditors. The spread of accounting scandals causes this condition.

According to Purnomo (2019), audit quality is the auditor's tendency to detect and disclose the existence of fraud in the client's financial statements. According to Yolanda \& Arza, (2019), Audit Quality is the accuracy of the information reported by the auditor by the audit standards used by the auditor, including details on accounting violations in the client company's financial statements. The Indonesian Institute of Certified Public Accountants (IAPI) issued a Draft Guide to Audit Quality Indicators for Public Accounting Firms on October 17, 2016. In this guide, indicators of audit quality at the KAP level, which include audit engagements on financial statements conducted by Public Accountants are as follows: Auditor Competence, Ethics, and Auditor Independence, Use of Engagement Key Personnel Time, Quality Control, Result of Quality Review Inspection of External and Internal Parties, Engagement Control Range, KAP Organization and Governance and fees policy.

Audit tenure is the period of engagement between the auditor and the company being audited (auditee). An engagement period that is too long can lead to a special relationship between the auditor and the client that can affect the auditor's quality. Sochib (2018) auditor tenure (KAP) shows the length of the relationship between the auditor and the client. Long auditor tenure can improve auditor competence. Auditors can base their audit decisions on the client's extensive knowledge, which has developed over time.

Auditor reputation is an image or good name owned and attached to an auditor for the work (audit quality) that has been achieved. Audit reputation is needed to support an auditor's career in the future. For this reason, it is necessary for the responsibility of an auditor always to provide information and audit services that are good, honest, and fair as well as beneficial for the decision-making of interested parties. According to Sochib (2018) in his book, auditors are responsible for providing high-quality information useful for decision making. Auditors with a good reputation tend to issue a going concern audit opinion if the client has a problem related to the company's going concern.

Profitability is the main ratio in a company's financial statements. The main goal of the company is to get the maximum profit. The profitability ratio is used to see how effective a company is in achieving its goals (Saputra and Asyik, 2017). From several profitability ratios that are commonly used, and based on several previous studies, researchers chose to proxy profitability using Return on Assets (ROA).

Based on theory and previous studies, the hypotheses in this research as follows:

$\mathrm{H}_{1}$ : It is suspected that audit rotation has a significant effect on audit quality

$\mathrm{H}_{2}$ : It is suspected that audit tenure significantly affects audit quality.

$\mathrm{H}_{3}$ : It is suspected that the auditor's reputation has a significant effect on audit quality

$\mathrm{H}_{4}$ : It is suspected that audit rotation significantly affects audit quality with profitability as a moderating variable.

$\mathrm{H}_{5}$ : It is suspected that audit tenure significantly affects audit quality with profitability as a moderating variable.

$\mathrm{H}_{6}$ : It is suspected that auditor reputation significantly affects audit quality with profitability as a moderating variable.

\section{Method}

The research object is a manufacturing company listed on the Indonesia Stock Exchange (IDX) in 2015-2019. The financial data studied are the company's financial statements for 2015-2019. The population in this study are manufacturing companies listed on the Indonesia Stock Exchange (IDX) in 2015-2019. Manufacturing companies listed on the Indonesia Stock Exchange (IDX) are research objects that present complete 
financial reports and are published in the form of an annual report. Sampling in this research must be carried out so that samples are obtained that can function or can describe the actual state of the population, in other terms it must be representative (represent). The sample selection method used purposive sampling, namely selecting samples based on certain criteria and systematics.

Table 1. Sample Determination

\begin{tabular}{clc}
\hline No. & \multicolumn{1}{c}{ Criteria } & Total \\
\hline 1 & $\begin{array}{l}\text { Manufacturing companies listed } \\
\text { on the Indonesia Stock }\end{array}$ & 184 \\
& $\begin{array}{l}\text { Exchange for the period 2015- } \\
2019\end{array}$ \\
$2 \quad \begin{array}{l}\text { Manufacturing companies that } \\
\text { were delisted during 2015-2019 } \\
\text { Manufacturing companies that } \\
\text { suffered losses on the } \\
\text { Indonesian stock exchange for } \\
\text { the 2015-2019 period } \\
\text { Manufacturing companies that } \\
\text { do not use the rupiah currency in } \\
\text { issuing a financial statement on } \\
\text { the Indonesian stock exchange } \\
\text { for 2015-2019 } \\
\quad \text { Total }\end{array}$ \\
\end{tabular}

The variables used in this study are Tax Aggressiveness (Y) as the dependent variable, Institutional ownership (X1), Independent Commissioners (X2), Corporate Social Responsibility (X3), and independent variable. And the moderating variable Firm Size (Z).

The audit quality variable is measured using a dummy variable (Andriani, 2017). If the company's financial statements receive an unqualified opinion, it is coded 1 , while other than an unqualified opinion it is coded 0 .

A public accounting firm may only audit the same company for five consecutive years and three consecutive years for a public accountant. However, several companies change auditors before five consecutive years (voluntary) (Andriani, 2017). Audit rotation is the change of public accountants to provide audit services to clients. Audit rotation is measured using a dummy variable, if the company rotates it is given a value of 1 and if the company does not rotate it is given a value of 0 (Irma.FA\&Kristianto, 2020).

Audit tenure is measured by calculating the number of years of engagement in which auditors from the same KAP perform audit engagements with clients (auditees). The initial engagement year begins with the number 1 and is added by the number 1 for the following year.
This study is divided into two groups, namely KAPs affiliated with the Big Four and KAPs not affiliated with the Big Four. Auditor reputation is measured by using a dummy variable. Where will be given a value of 1 for companies audited by the Big Four KAP, while if a non-Big Four KAP audits the company it will be given a value of 0 (Irma.FA\&Kristianto, 2020).

The greater the ROA, the better the company's performance because the greater the rate of return. Profitability. Kasmir (2019) explains that the definition of profitability is the ratio used to assess the company's ability to seek profit. The level of management effectiveness in a company can also be shown from the profitability ratio.

Data analysis by used logistic regression as follows:

$$
\pi(\mathbf{x})=\frac{\exp \left(\beta_{0}+\beta_{1} x_{1}+\cdots+\beta_{p} x_{p}\right)}{1+\exp \left(\beta_{0}+\beta_{1} x_{1}+\cdots+\beta_{p} x_{p}\right)}
$$

$$
\begin{array}{ll}
\pi & : \text { Audit Quality } \\
\alpha & : \text { Constant } \\
\beta & : \text { Regression Coefficient } \\
\mathrm{X}_{1}: \text { Audit Rotation } \\
\mathrm{X}_{2}: \text { Audit Tenure } \\
\mathrm{X}_{3}: \text { Auditor Reputation } \\
\mathrm{Z}: \text { Profitability }
\end{array}
$$

\begin{tabular}{|c|c|c|c|c|c|}
\hline VARIABLE & X1_ARo & $\mathrm{X}_{2 \_} \mathrm{ATe}$ & $\mathrm{X}_{3 \_} \mathrm{ARe}$ & Z_Prof & $\bar{Y}$ Y_AQu \\
\hline $\mathrm{N}$ & 325 & 325 & 325 & 325 & 325 \\
\hline Minimum & 0 & 1 & 0 & 0 & 0 \\
\hline Maximum & 1 & 5 & 1 & 1 & 1 \\
\hline Mean & 0.68 & 2.43 & 0.58 & 0.09 & 0.65 \\
\hline Std. Dev. & 0.468 & 1.354 & 0.494 & 0.095 & 0.478 \\
\hline
\end{tabular}

\section{Result and Discussion}

\section{Result}

The research data becomes the dependent variable (Y) Audit Quality, while the independent variables are Audit Rotation $\left(\mathrm{X}_{1}\right)$, Audit Tenure $\left(\mathrm{X}_{2}\right)$, Auditor Reputation $\left(\mathrm{X}_{3}\right)$ and Profitability $(\mathrm{Z})$.

Table 2. Descriptive Statistical Test Results

Data processed by authors

Audit Quality has a minimum value of 0 , the maximum value is 1 . While the mean value is 0.65 with a standard deviation of 0.478 . Audit rotation has a minimum value of 0 with a maximum value of 1 . While the mean value is 0.68 with a standard deviation of 0.468 . Audit Tenure has a minimum value of 1 with a maximum value of 5 . While the mean value is 2.14 with a standard deviation of 1.354 . Auditor reputation has a minimum value of 0 and a maximum value of 1 . While the mean value is 0.58 with a standard deviation of 0.494. Profitability has a minimum value of 0 and a maximum value of 1 . While the mean value is 0.09 with a standard deviation of 0.095 . 


\begin{tabular}{|c|c|c|c|c|}
\hline & B & S.E. & Wald & Sig. \\
\hline X1_ARO &,- 812 & ,367 & 4,879 & ,027 \\
\hline X2_ATE & ,071 &, 129 & ,306 &, 580 \\
\hline X3_ARE & 1,311 & ,391 & 11,230 & ,001 \\
\hline Z_PROF & 6,999 & 5,241 & 1,783 & ,182 \\
\hline $\mathrm{X} 1 * \mathrm{Z}$ & 1,171 & 2,623 & ,199 & ,655 \\
\hline $\mathrm{X} 2 * \mathrm{Z}$ & , 370 & 1,030 &, 129 &, 720 \\
\hline $\mathrm{X} 3 * \mathrm{Z}$ & $-11,237$ & 4,481 & 6,288 & ,012 \\
\hline Constant & , 192 & .528 & .132 & .716 \\
\hline
\end{tabular}

The regression coefficient value of the Audit Rotation variable $\left(\mathrm{X}_{1}\right)$ is positive at -0.812 . This shows that for every 1 unit increase in Audit Rotation, Audit Quality (Y) will decrease by 0.812 with Audit Tenure $\left(\mathrm{X}_{2}\right)$ variable units and Profitability $(\mathrm{Z})$ variable being ignored or worth 0 .

The regression coefficient value of the Audit Tenure variable $\left(\mathrm{X}_{2}\right)$ is 0.071 . This shows that every increase in Audit Tenure1 unit, Audit Quality (Y) will increase by 0.071 with Auditor Reputation variable unit $\left(\mathrm{X}_{3}\right)$ and Profitability variable $(\mathrm{Z})$ ignored or worth 0 .

The Auditor's Reputation variable $\left(\mathrm{X}_{3}\right)$ is 1.311. This shows that for every 1 unit increase in Auditor Reputation, Audit Quality (Y) will increase by 1.311 with units of Audit Rotation variable $\left(\mathrm{X}_{1}\right)$, Audit Tenure variable and Profitability variable $(\mathrm{Z})$ being ignored or worth 0 .

The regression coefficient value of the $\mathrm{X}_{1} * \mathrm{Z}$ variable is 1.171 . This means that if profitability increases by one unit, then the company's value increases by 1.171 with the assumption that the variables of Audit Rotation, Audit Tenure and Auditor Reputation remain constant.

The regression coefficient value of the $\mathrm{X}_{2} * \mathrm{Z}$ variable has a positive value of 0.370 . This means that if Profitability decreases by one unit, then the company's value increases by 0.370 with the assumption that the variables of Audit Rotation, Audit Tenure and Auditor Reputation remain constant.

The regression coefficient value of the $\mathrm{X}_{3} * \mathrm{Z}$ variable has a positive value of $-11,237$. This means that if Profitability decreases by one unit, then the company's value decreases by 11.237 with the assumption that the variables of Audit Rotation,
Auditor Tenure and Auditor Reputation remain constant.

Table 4. The Feasibility of the Regression

\begin{tabular}{cc|c|c}
\hline Step & Chi-square & df & Sig. \\
\hline 1 & 7,299 & 8 &, 505 \\
\hline \multicolumn{2}{l}{ Data processed by authors }
\end{tabular}

Model presents the results of the feasibility test of the regression model that the Chi-Square value is 7.299 with a significance of 0.505 . Based on these results, because the significant value is $>0.05$, the model can be concluded to be able to predict the observed value or the model is said to be fit with the data and the model is acceptable so that this model can be used for further analysis.

The results of the influence of Audit Rotation, Audit Tenure and Auditor Reputation together affect Audit Quality with Profitability as a moderating variable in Table 4.11 showing the Chisquare value of 21.296 with a significant value of $0.003<0.05$. So, it can be concluded that it is accepted. So, it can be said that Profitability strengthens the influence of Audit Rotation, Audit Tenure and Auditor Reputation together on Audit Quality.

Table 5. Omnibus Test of Model Coefficient

\begin{tabular}{llll}
\hline & Chi-square & df & Sig. \\
\hline Step & 21,296 & 7 &, 003 \\
Block & 21,296 & 7 &, 003 \\
Model & 21,296 & 7 &, 003 \\
\hline
\end{tabular}

Data processed by authors

Table 6. Model Summary

\begin{tabular}{cccc}
\hline Step & $\begin{array}{c}-2 \text { Log } \\
\text { likelihood }\end{array}$ & $\begin{array}{c}\text { Cox \& Snell } \\
\text { R Square }\end{array}$ & $\begin{array}{c}\text { Nagelkerke } \\
\text { R Square }\end{array}$ \\
\hline 1 & $399.853^{\mathrm{a}}$ &, 063 &, 687 \\
\hline
\end{tabular}

Data processed by authors

value of the coefficient of determination in the logistic regression model is indicated by the value of Nagelkerke's R Square. The value of Nagelkerke's $\mathrm{R}$ Square varies between 1 (one) and 0 (zero). not goodness of fit. This shows that a value close to 1 means that the independent variable provides almost all the information needed to predict the variation of the independent variable. The greater the value of Nagelkerke's R Square (close to 100\%) the better the regression model. Based on the results of the SPSS output, the Negelkerke R Square value shown in table 4.13 is 0.687 . This means that the variability of the dependent variable, namely Audit Quality, which can be explained by the two independent variables, namely Audit Rotation in this study, is $68.7 \%$. 


\section{Discussion}

The results of the t-test analysis of the Auditor's Reputation variable show that the regression coefficient is -0.690 with a significant value of 0.012 $<0.05$. So it can be concluded that the first hypothesis (H1) is accepted. So it can be said that Audit Rotation has a significant and significant effect on Audit Quality in manufacturing companies listed on the Indonesia Stock Exchange in 2015-2019. The results of this study show the same results as research conducted by (Listiya Ike Purnomo, 2019) where audit rotation has an influence on audit quality and this research is consistent with research conducted by (Wida Tri Septia, CherryaDhiaWenny, 2017) finding audit rotation simultaneously affect the Quality of Audit. The auditor's task as an appraiser of a company sees the fairness of the presentation of financial statements that must be reported by the auditor with good audit quality with an unqualified opinion. The opinion expressed by the auditor is based on the findings of evidence and the state of the company that has been audited. Auditors as independent external parties must provide quality audited reports, for this reason, audit rotation is needed as an action that minimizes the cooperation between the company and the auditor in indications of fraud.

The results of the t-test analysis of the Audit Tenure variable showed a regression coefficient of 0.087 with a significant value of $0.346>0.05$. So it can be concluded that the second hypothesis (H2) is rejected. So it can be said that Audit Tenure has no significant effect on Audit Quality in manufacturing companies listed on the Indonesia Stock Exchange in 2015-2019. The results of this study show the same results as research conducted by (Wida Tri Septia, CherryaDhiaWenny, 2017) which partially shows that Audit Tenure has no effect on audit quality and research by (Stephanie Yolanda, FefriIndraArza, 2019) finds that Audit Tenure has no significant effect on Audit Quality. Audit tenure is the period of the auditor's relationship with his client, or it can also be interpreted as the period of engagement (involvement) that exists between the Public Accounting Firm (KAP) and the client who has agreed upon audit services (Rizkiani.NM, 2019).

The results of the t-test analysis of the Auditor's Reputation variable showed a regression coefficient of 0.544 with a significant value of 0.028 $<0.05$. So it can be concluded that the third hypothesis (H3) is accepted. So it can be said that Auditor Reputation is influential and significant on Audit Quality in manufacturing companies listed on the Indonesia Stock Exchange in 2015-2019.

The results of this study show the same results as research conducted by (LulukIndriani, Moh. Amin, 2020) partially, Auditor Reputation has a significant effect on Audit Quality and research
(Luthfisahar, 2020) found that Auditor Reputation has a significant effect on Audit Quality. The hypothesis shows that the auditor's reputation significantly affects audit quality. The results of this study can also be information for the public so that they choose KAP based on information on audit quality and not only based on size. For the public accounting professional association, this research is expected to provide guidance to members of the association so that members maintain their integrity and independence in carrying out audit duties so that the public accounting profession remains trusted by the public.

The results of the t-test analysis of the Profitability variable on Audit Rotation show a regression coefficient of 1.171 with a significant value of $0.655>0.05$. So it can be concluded that the second hypothesis (H4) is rejected. So it can be said that profitability weakens the influence of Audit Rotation on Audit Quality in manufacturing companies listed on the Indonesia Stock Exchange in 2015-2019.

The profitability variable on audit rotation before using the moderating variable showed a significant value of 0.012 and after using the moderating variable, it was 0.027 . So it can be said that profitability weakens the influence of audit rotation on audit quality. Return on Assets (ROA) is a ratio that shows the results (return) on the total assets used in the company. In addition, ROA provides a better measure of the company's profitability because it shows the effectiveness of management in using assets to generate revenue. The greater the ROA, the better the company's performance, because the greater the rate of return. Profitability.

The results of the t-test analysis of Profitability on Audit Tenure showed a regression coefficient of 0.370 with a significant value of 0.720 > 0.05 . So it can be concluded that the second hypothesis (H5) is rejected. So it can be said that Profitability weakens the influence of Audit Tenure on Audit Quality in manufacturing companies listed on the Indonesia Stock Exchange in 2015-2019.

Before using the moderating variable, the profitability variable on Audit Tenure showed a significant value of 0.346 and after using the moderating variable was 0.580 . So it can be said that Profitability strengthens the influence of Auditor's Reputation on Audit Quality. Return on Assets (ROA) is a ratio that shows the results (return) on the total assets used in the company. In addition, ROA provides a better measure of the company's profitability because it shows the effectiveness of management in using assets to generate revenue. The greater the ROA, the better the company's performance, because the greater the rate of return. Profitability. 


\section{Conclusion}

Based on the results of the analysis and discussion regarding the Effect of Audit Rotation, Audit Tenure and Auditor Reputation with Profitability as a Moderating Variable, the following conclusions can be drawn:

1. Audit rotation significantly affects audit quality in manufacturing companies listed on the Indonesia Stock Exchange (IDX) in 20152019.

2. Tenure audit has no significant effect on audit quality in manufacturing companies listed on the Indonesia Stock Exchange (IDX) in 2015-2019.

3. Auditor reputation significantly affects audit quality in manufacturing companies listed on the Indonesia Stock Exchange (IDX) in 20152019.

4. Profitability as a moderating variable has no effect on Audit Tenure on Audit Quality in manufacturing companies listed on the Indonesia Stock Exchange (IDX) in 20152019.

5. Profitability as a moderating variable has no effect on Audit Tenure on Audit Quality in manufacturing companies listed on the Indonesia Stock Exchange (IDX) in 20152019.

6. Profitability as a moderating variable affects Auditor Reputation on Audit Quality in manufacturing companies listed on the Indonesia Stock Exchange (IDX) in 20152019.

Based on the conclusions above, several suggestions can be put forward which are expected to be useful for the company or other interested parties. The recommendations given include:

For management, in making policy on the selection of a Public Accountant office, more attention should be paid, choose a representative KAP and an auditor who is responsible if given the obligation to analyze financial reports according to the standards and rules that have been determined.

For companies

It is better to choose executives who pay more attention to all aspects that will be the key to making the right decisions to carry out company activities, both in the selection of KAP and other decisions. Company executives are advised to control the stakeholders in the decision-making process so that it can produce the best decisions for the survival of the company. Because in the hands of the executive all decisions and the level of success of a company in carrying out its activities.

For Investors. It is recommended that investors who want to invest their shares first look at the annual report of the company that is the target of investment to see a general picture of the company, especially the auditor's report and the auditing public accounting firm because of how the condition of the company will be presented in the auditor's report.

\section{References}

Dian Indri Purnamasari, H. K. S. N. (2019). The Effect of Auditor Reputation, Audit Tenure, and Firm Size on Audit Quality ( A Study of Manufacturing Companies Listed on the Indonesia Stock Exchange for the 2013-2017 Period ). International Journal of Computer Networks and Communications Security, 7(6), 104-108.

Fitria Ade Irma, R., \& Kristianto, D. (2020). Pengaruh Audit Tenure, Rotasi Auditor, Reputasi Auditor, dan Spesialisasi Auditor terhadap Kualitas Audit. Jurnal Akuntansi Dan Sistem Teknologi Informasi, 15(4), 6.

Listiya Ike Purnomo, J. A. (2019). Pengaruh Fee Audit, Audit Tenure, Rotasi Audit Dan Reputasi Auditor Terhadap Kualitas Audit. Jurnal Ekonomi \& Bisnis, 1(1), 50-61.

Mulyadi, R. (2017). Pengaruh Karakteristik Komite Audit Dan Kualitas Audit Terhadap Profitabilitas Perusahaan. Jurnal Akuntansi, 4(2), 22-35.

Nada Pertiwi, E. N. (2020). Pengaruh Kualitas Komite Audit,Workload Dan Rotasi Auditor Terhadap Kualitas Audit. Jurnal Eksplorasi Akuntansi, 2(4), 3720-3736. file://F:/ali/payanname/Article.pdf

Nadia Meida Rizkiani, A. N. (2019). Pengaruh Audit Tenure, Ukuran Perusahaan, Spesialisasi Auditor dan Leverage Terhadap Kualitas Audit (Studi Pada Perusahaan Infrastruktur, Utilitas dan Transportasi Yang Terdaftar Di Bursa Efek Indonesia Tahun 2013-2017). Jurnal Aksara Public, 3(2), 109-119.

Ninik Andriani, N. (2017). Pengaruh Fee Audit, Audit Tenure, Rotasi Audit Dan Reputasi Auditor Terhadap Kualitas Audit (Studi Empiris Pada Perusahaan Manufaktur yang Terdaftar di Bursa Efek Indonesia Tahun 2013-2015). Riset Akuntansi Dan Keuangan Indonesia, 3(1), 2939. https://doi.org/10.23917/reaksi.v3i1.5559

Ranti Dewi Fortuna, E. S. (2020). Pengaruh Umur Perusahaan, Ukuran Perusahaan, Reputasi Auditor, dan Pergantian Auditor. Jurnal Eksplorasi Akuntansi, 2(3), 2912-2928.

Rizki Wahyu Wulan Lutfi Yanti, Sochib, P. W. (2018). Pengaruh Fee Audit, Audit Tenure Dan 
Reputasi Auditor Terhadap Kualitas Audit Pada Perusahaan Sektor Industri Dasar dan Kimia Yang Terdaftar di Bursa Efek Indonesia. Jurnal Riset Akuntansi, 1(1), 1-7.

Stephanie Yolanda, Fefri Indra Arza, H. (2019). Pengaruh Audit Tenure, Komite Audit dan Audit Capacity Stress Terhadap Kualitas Audit. Jurnal Eksplorasi Akuntansi, 1(2), 543-555.

Zahra Ismi Fauziyyah, P. (2020). Pengaruh Audit Fee, Audit Tenure, dan Rotasi Audit Terhadap Kualitas Audit. Jurnal Monex, 9(1), 1-17. 